\title{
Jacek Szołtysek
}

E-mail: jacek.szoltysek@ue.katowice.pl; nr ORCID: 0000-0003-3266-0241

Uniwersytet Ekonomiczny w Katowicach, Wydział Zarządzania

\section{Rafał Otręba}

E-mail: rafal.otreba@ue.katowice.pl; nr ORCID: 0000-0001-9921-1294

Uniwersytet Ekonomiczny w Katowicach, Wydział Zarządzania

\section{Gospodarka współdzielenia w dyskursie logistycznym}

\section{Sharing economy in Logistics discourse}

\begin{abstract}
Artykuł porusza kwestie wpływu gospodarki współdzielenia na rozwój dyskursu logistycznego. Zmiana podejścia ludzi do kwestii posiadania oraz dążenie do przebywania we wspólnotach zrodziło koncepcję współdzielenia. Przedstawione rozwiązania, warunkowane przede wszystkim rozwojem technologicznym współczesnego świata, wymagają redefinicji struktur i procesów logistycznych. Z drugiej strony otwierają także dyskurs logistyczny na nowe wyzwania.
\end{abstract}

Stowa kluczowe:

gospodarka współdzielenia, logistyka, logistyka społeczna.

The article discusses the impact of the sharing economy on the development of logistic discourse. Changing people's attitude to the issue of ownership and striving to stay in communities gave rise to the concept of sharing. The presented solutions, conditioned primarily by the technological development of the modern world, require a redefinition of logistics structures and processes. On the other hand, they also open a logistics discourse on new challenges.

Key words:

sharing economy, logistics, social logistics.

str. $2-8$

\section{Bibliografia}

Aronson, E. (1978). Człowiek - istota społeczna. Warszawa: PWN

Bębenek, S. T. (1981). Myślenie o przyszłości. Warszawa: PIW. Toffler, A. (1990). Trzecia fala. Warszawa: PIW.

Botsman, R., Rogers, R. (2010). What's Mine is Yours: The Rise of Collaborative Consumption. New York: HarperCollins Publishers.

DeLanda, M. (2008). A new philosophy of society: assemblage theory and social complexity. London and New York: Bloomsbery Publishing Plc.

Felson, M., Spaeth, J. L. (1978). Community Structure and Collaborative Consumption: A routine activity approach. American Behavioral Scientist, (21).

Jaros, B. (2016). Bariery i pozytywne tendencje w rozwoju zrównoważonej konsumpcji w Polsce. Białystok: Ekonomia i Środowisko, (57).

Jonek-Kowalska, I. (2016). Implementacja koncepcji społecznej odpowiedzialności w organizacjach $i$ gospodarce. Zabrze: Śląskie Centrum Etyki Biznesu i Zrównoważonego Rozwoju.

Markley, O. W. (1995). A Normative Forecast for the Future of ,,SpaceShip Earth”. The Fourth Wave.

Rudawska, I. (2016). Ekonomia dzielenia się, czyli konsumpcja współdzielona i inne formy alternatywnego dostępu do dóbr. Katowice: Zeszyty Naukowe Uniwersytetu Ekonomicznego w Katowicach, (254). 
Szołtysek, J. (2016). Ekonomia współdzielenia a logistyka miasta — rozważania o związkach. Gospodarka Materiałowa i Logistyka, (11).

Szołtysek, J. (2017). Ideologia w logistyce. Gospodarka Materiałowa i Logistyka, (8).

Szołtysek, J. (2015a). Pryncypium logistyki. Logistyka, (1).

Szołtysek, J., Jeż, R., Twaróg, S. (2015c). Kompetencje społeczne w okresie kształcenia zawodowego na potrzeby logistyki społecznej. Katowice: Studia Ekonomiczne. Zeszyty Naukowe Uniwersytetu Ekonomicznego w Katowicach, (249).

Szołtysek, J., Twaróg, S., Płaczek, E., Majewska, J. (2015b). Wrażliwość społeczna jako kompetencja przyszłych menedżerów logistyki - rozpoznanie wstępne. Modelowanie procesów i systemów logistycznych (Część XIV). Gdańsk: Zeszyty Naukowe Uniwersytetu Gdańskiego, (56).

Szołtysek, J., Twaróg, S. Płaczek, E. (2014). Kompetencje menedżerów firm świadczących profesjonalne usługi logistyczne w obszarze logistyki społecznej. W: J. Matysiewicz (red.), Ustugi profesjonalne w globalnej gospodarce. Warszawa: Placet.

Toffler, A. (1990). Trzecia fala. Warszawa: PIW.

Urry, J. (2009). Socjologia mobilności. Warszawa: PWN.

Walsh, B. (2011). Today’s Smart Choice: Don’t Own. Share. Time, 3 (17), 8-10.

\section{Źródla internetowe:}

https://www.couchsurfing.com/ (dostęp: 20.12.2018).

https://play.google.com/store/apps/details?id=com.greasedwatermelon.leftoverswap (dostęp 20.12.2018).

http://www.thepeoplewhoshare.com/blog/what-is-the-sharing-economy/ (dostęp z dnia 20.12.2018). 